\title{
Preliminary responses of some Thai rice cultivars to simulated acid rain stress during seed germination
}

\author{
Jakkrit Sreesaeng ${ }^{\mathrm{a}, \mathrm{b}, \mathrm{c}}$, Panuphong Kongchiu ${ }^{\mathrm{a}, \mathrm{c}}$, Sutkhet Nakasathien ${ }^{\mathrm{a}, \mathrm{c}, *}$ \\ a Center for Advanced Studies for Agriculture and Food (CASAF), Kasetsart University Institute for \\ Advanced Studies, Kasetsart University, Bangkok 10900 Thailand \\ b Lamtakong Research Station, Expert Centre of Innovative Agriculture, Thailand Institute of Scientific \\ and Technological Research (TISTR), Pathum Thani 12120 Thailand \\ c Department of Agronomy, Faculty of Agriculture, Kasetsart University, Bangkok 10900 Thailand
}

*Corresponding author, e-mail: agrskn@ku.ac.th

Received 16 Mar 2020

Accepted 28 Feb 2021

\begin{abstract}
Germination response of nine Thai rice (Oryza sativa) cultivars was investigated under simulated acid rain at $\mathrm{pH}$ values of $2.5,3.5,4.5,5.5$ and a control at $\mathrm{pH} 6.5$ using a split-plot in completely randomized design (CRD) with three replications as main plots and subplots. Germination percentage, seedling characteristics and inhibitory responses were evaluated. Results showed that rice seed germination decreased after exposure to simulated acid rain of $\mathrm{pH} 2.5$, 3.5 and 4.5 compared to the control. Acid rain significantly decreased seedling root length, root-to-shoot ratio and crown roots per seedling while $\mathrm{pH} 2.5$ completely inhibited all the investigated seedling characteristics. Average values of germination percentage reduction were highly significant in KDML105 and RD27 cultivars while acid rain stimulated rice seed germination in HPYTD, RD57, MLL and TTCP, suggesting that these cultivars are tolerant to acid rain stress during seed germination.
\end{abstract}

KEYWORDS: rice, germination, seedling characteristics, simulated acid rain, stress

\section{INTRODUCTION}

Acid rain is a serious global environmental problem $[1,2]$ that impacts agriculture, forestry and human health [3]. Acid monitoring is conducted on both wet and dry depositions to assess the ecological impacts on soil, vegetation and inland aquatic environments. In southern Asia, the five-year average $\mathrm{pH}$ of rainwater is less than 5.0 at over $60 \%$ of the Acid Deposition Monitoring Network in East Asia (EANET) monitoring sites and less than 4.6 at several sites [4]. Previous studies revealed that samples of acid rainwater averaged $\mathrm{pH}<5.6$ [5]. A report covering the Ambient Air Quality Monitoring Network in Thailand operated by the Pollution Control Department (PCD) revealed that average $\mathrm{pH}$ values of rainwater did not change from 2003 to 2008 at each study site. In western areas of Thailand, $\mathrm{pH}$ values of rainwater ranged from 4.0 to 7.8 with an average of 6.1. Mallika and Rattapon [6] reported $22 \%$ of 319 rain events as acidic rainwater $(\mathrm{pH}<5.6)$. Chemical compositions of atmospheric precipitation and contributing sources to acidity were studied in the Mae Moh Valley,
Northern Thailand. Results showed concentrations of major ionic species as $\mathrm{HCO}_{3}^{-}>\mathrm{NH}_{4}^{+}>\mathrm{Ca}^{2+}>$ $\mathrm{SO}_{4}^{2-}>\mathrm{Na}^{+}>\mathrm{Cl}^{-}>\mathrm{NO}_{3}^{-}>\mathrm{K}^{+}>\mathrm{Mg}^{2+}>\mathrm{H}^{+}$ $>\mathrm{PO}_{4}^{3-}>\mathrm{F}^{-}$. Rainwater acidity was significantly neutralized by alkaline species [7]. The Ambient Air Quality Monitoring Network in Thailand reported the main cation and anion of acid rainwater as $\mathrm{NH}_{4}^{+}$ and $\mathrm{SO}_{4}^{2-}$, respectively [5].

Rice is a major worldwide food security crop and a main export product of Thailand. Direct seedling planting is the most common cultural practice in rice fields around the world including Thailand. A previous study indicated that $22 \%$ of the total rain events in Thailand were acidic. Rice seed germination and seedling development are affected by acid rain events caused by increasing emissions of $\mathrm{SO}_{2}$ and $\mathrm{NO}_{\mathrm{x}}$. Germination is the first step for seed development into new plants when conducive environmental conditions trigger growth [8,9]. Effects of simulated acid rain on plant health have been studied in many species such as rice, tomato, wheat, mountain birch, rape and trees [10-12] and also during seed germination in many plant species including rice. Acid rain caused different responses 
on seed germination depending on plant species and plant developmental stage. Wang et al [13] studied the long-term effects of simulated acid rain on the stable forest species Pinus massoniana Lamb. The results revealed that both biochemical and physiological processes responded to acid rain while shortterm effects of simulated acid rain at $\mathrm{pH} 2.0$ on five hardwood species resulted in extensive foliar damage, decline in chlorophyll content and retardation of seedling growth [14]. Fan and Li [15] reported that simulated acid rain at $\mathrm{pH} 2.0$ inhibited seed germination and seedling growth of five broadleaved species. Feng et al [16] suggested rice was acid resistant while Zabawi et al [17] reported negative effects of simulated acid rain at $\mathrm{pH} 3.5$ on seed germination and seedling growth of Malaysia rice MR 84 cultivar. Their findings revealed significantly reduced seed germination, tiller and leaf number at percentages of 4, 14 and 10, respectively. These results suggested that acid rain affected a wide range of plant species at different stages of plant growth and development. The detrimental effect of acid rain on plant health depends on species, growth stage, adaptation of the plant, acidity level of rainwater and rain time period. However, to the best of our knowledge, the effect of simulated acid rain on seed germination and seedling development of Thai rice varieties has never been reported. Hence, this study investigated preliminary responses of selected Thai rice varieties exposed to simulated acid water at different $\mathrm{pH}$ levels during seed germination and at the seedling stage.

\section{MATERIALS AND METHODS}

\section{Preparation of simulated acid rain}

Simulated acid rain (SAR) was prepared using a buffer solution of $\mathrm{H}_{2} \mathrm{SO}_{4}$ and $\mathrm{HNO}_{3}$ in the ratio of 5 to $1 \mathrm{v}: \mathrm{v}$ by chemical equivalents [18] since most cations and anions of acid rain components comprise $\mathrm{NH}_{4}^{+}$and $\mathrm{SO}_{4}^{2-}$. Distilled water was added with $\mathrm{H}_{2} \mathrm{SO}_{4}$ and $\mathrm{HNO}_{3}$ solutions to prepare $\mathrm{pH}$ values at 2.5, 3.5, 4.5, 5.5 and a neutral solution of pH 6.5 as the control. The $\mathrm{pH}$ levels were measured by using a $\mathrm{pH}$ meter series $\mathrm{pH} 6+$ manufactured by EuTech Instruments Pte Ltd.

\section{Plant materials and treatments}

A germination test was performed to evaluate the effect of simulated acid water on nine rice (Oryza sativa) cultivars collected from various regions of
Thailand including RD21, Khao Dawk Mali 105 (KDML105), Khao Tah Haeng 17(KTH17), Cew Mae Jan (CMJ), RD57, Tubtim Chumphae (TTCP) or RD69, Haum Phaya Tongdum (HPYTD), Khao Kam Noi (KKN) and Mali Lueay (MLL). The nine samples represent five landraces (KTH17, CMJ, HPYTD, KKN and MLL) and four improved cultivars (RD21, KDML105, TTCP and RD57). The rice varieties/cultivars were classified as seven cooked rice (KTH17, HPYTD, MLL, RD21, KDML105, TTCP and $\mathrm{RD} 57$ ) and two sticky rice (CMJ and $\mathrm{KKN}$ ). The germination test was carried out using a splitplot completely random design (CRD) with five different $\mathrm{pH}$ levels as main plots and nine Thai rice cultivars as subplots with three replications. For seed germination testing, the nine rice cultivars were placed on paper in Petri dishes that had been sterilized in an automatic autoclave at 121 degrees Celsius under 15 pounds per square inch pressure for $30 \mathrm{~min}$. Twenty dishes of each cultivar were randomly divided into five treatments, and fifty healthy seeds were placed on one Petri dish per replication. Simulated acid solutions at different $\mathrm{pH}$ levels were added at about $15 \mathrm{ml}$ per dish continuously for 7 days, following the method described by Wang et al [18]. Germination percentage and abnormal seedling percentage were evaluated 7 days after germination. Seedling characteristics were studied for ten seedlings per replication at 7 days after germination. Abnormal seedlings were evaluated following the procedure laid down by the International Seed Testing Association [19]. Seedling characteristic data were collected including rootto-shoot ratio of length, seedling height, seedling root length, number of crown roots per seedling and root tip character. Promotional and inhibitory effects of shoot length, root length, root per shoot ratio, number of crown roots per seedling and seed germination were calculated by the equation $\% \mathrm{IN}=$ $\{(C-M) / C\} \times 100$, where $M$ is the average value of traits per replication of each treatment and $C$ is the average value of traits per replication of the control ( $\mathrm{pH}$ 6.5). If $\% \mathrm{IN}$ is $<0$, then inhibition will not occur, whereas \% IN $>0$ implies that treatment is stimulated [20]. Statistical analysis was performed using IRRISTAT version 7.2. Significant differences $(p<0.05)$ were analyzed using one-way ANOVA followed by Duncan's multiple range test (DMRT). Cluster analysis of the nine Thai rice cultivars was determined based on the Euclidean distance coefficient using germination percentage and seedling characteristics affected by simulated acid rain at different $\mathrm{pH}$ levels. 


\section{RESULTS}

\section{Effect of simulated acid rain on seed germination of selected Thai rice cultivars}

Germination percentage showed no interaction between $\mathrm{pH}$ level and rice cultivars. Rice germination percentage significantly decreased upon exposure to simulated acid rain at $\mathrm{pH} 2.5$ (6.89\%), and seed germination of RD27, RD57 and HPYTD as two improved cultivars and one landrace was completely inhibited. Average germination percentages of rice cultivars exposed to simulated acid rain at different $\mathrm{pH}$ levels ranged from 40.8 to $70.7 \%$ for HPYTD and KDML105 cultivars, respectively (Table 1 ). Tolerance ability of rice cultivars to simulated acid rain was separated into five groups by germination percentage as highly tolerant $(\geqslant 80 \%)$, tolerant $(60$ $79 \%$ ), moderate (40-59\%), sensitive (20-39\%) and highly sensitive cultivars (0-19\%). Results showed that moderately tolerant cultivars were RD57, MLL, KKN, KTH17 and HPYTD with average germination percentages of 52.2, 55.9, 45.8, 48.7 and $40.8 \%$, respectively. Highly tolerant cultivars were RD27, CMJ, KDML105 and TTCP with average germination percentages of $68.0,60.7,70.7$ and $60.6 \%$, respectively. The quality of seed samples used in this study was an important concern because germination percentage of the control treatment was low. Different sources of rice seed were the main factor for diverse seed quality. Results were compared between the control at $\mathrm{pH} 6.5$ and other $\mathrm{pH}$ levels to evaluate and clarify the information. Average value of seed germination for each cultivar was not the best absolute indicator of rice cultivar response to simulated acid rain.

Abnormal seedling percentages of the nine Thai rice cultivars during seed germination were the same as previously described by ISTA [19]. No interactive effect was found between $\mathrm{pH}$ levels and rice cultivars. Surprisingly, abnormal seedling percentages of KKN and HPYTD at pH 2.5 were highest compared to the others.

\section{Effect of simulated acid rain on seedling characteristics of selected Thai rice cultivars}

Seedlings represent the first stage of plant growth and development to obtain produce yield. Five characteristics of rice seedlings exposed to simulated acid rain were investigated including shoot height, root length, root per shoot ratio of length, number of crown roots per seedling and root tip that was studied using a stereomicroscope (Fig. 1). The results showed that root tips of all cultivar seedlings

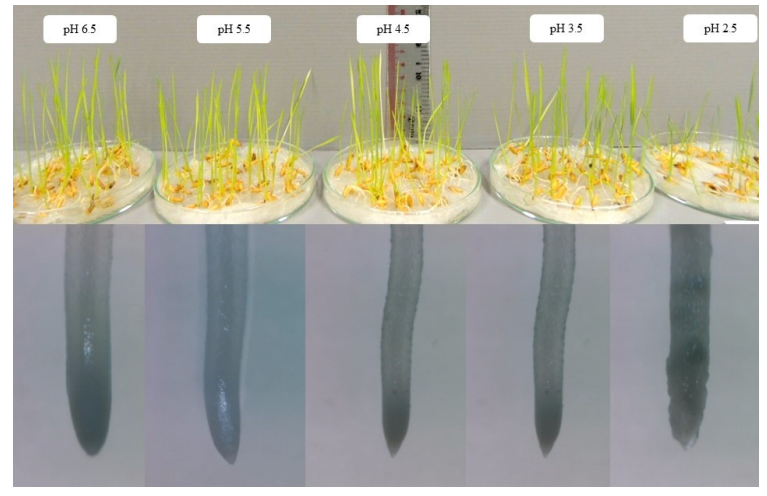

Fig. 1 Seed germination and root tip characteristics of RD57 cultivar exposed to simulated acid rain at different pH levels.

developed an irregular form as acidity increased to $\mathrm{pH} 2.5$ compared with other $\mathrm{pH}$ levels, indicating that simulated acid rain at $\mathrm{pH} 2.5$ inhibited root formation and root cell differentiation.

The effect of simulated acid rain on seedling characteristics of nine Thai rice cultivars revealed no interaction between $\mathrm{pH}$ levels and rice cultivars in all traits (Table 2). Seedling shoot height showed highest average values for MLL $(8.24 \mathrm{~cm})$, followed by RD27 $(6.95 \mathrm{~cm})$, KDML105 $(6.79 \mathrm{~cm})$, CMJ $(6.67 \mathrm{~cm})$ and KTH17 $(6.50 \mathrm{~cm})$ cultivars. Seedling shoot heights of CMJ, KTH and RD57 cultivars decreased when acidity of simulated acid rain increased while average value of seedling shoot heights of RD27, KDML105, MLL, TTCP, KKN and HPYTD cultivars increased when acidity of simulated acid rain increased. This result indicated that the rice cultivars responded differently to water acidity. Rice cultivars also have diverse growth habits. Native rice cultivars have developed greater internode elongation than improved cultivars. This information can be compared with the control condition.

Seedling root length was significantly affected by $\mathrm{pH}$ level. Results revealed that seedling root length was longest at $\mathrm{pH} 6.5-5.5(7.66-7.27 \mathrm{~cm})$ followed by $\mathrm{pH} 4.5-3.5(6.68-6.63 \mathrm{~cm})$ with the shortest at pH $2.5(2.73 \mathrm{~cm})$. Root length of all cultivars decreased as the acidity of simulated acid rain increased. Average values of rice cultivars showed that KTH17, RD57, MLL and TTCP cultivars had the longest root length. This result indicated that root length of seedlings was sensitive to simulated acid rain at $\mathrm{pH} 4.5-2.5$.

The effect of simulated acid rain on root/shoot 
Table 1 Mean values of seed germination of nine Thai rice cultivars exposed to simulated acid rain at different $\mathrm{pH}$ levels.

\begin{tabular}{|c|c|c|c|c|c|c|c|c|c|c|}
\hline \multirow{2}{*}{ pH level } & \multicolumn{9}{|c|}{ Cultivar } & \multirow{2}{*}{ Average } \\
\hline & $\mathrm{RD} 27$ & CMJ & KDML105 & KTH17 & RD57 & MLL & ТTCP & $\mathrm{KKN}$ & HPYTD & \\
\hline \multicolumn{11}{|c|}{ Seed germination percentage (A) } \\
\hline pH 6.5 & 80.5 & 77.5 & 87.5 & 65.5 & 72.5 & 67.0 & 73.0 & 60.5 & 61.0 & $71.67^{\mathrm{a}}$ \\
\hline pH 5.5 & 84.5 & 76.0 & 94.0 & 57.0 & 76.0 & 61.0 & 73.5 & 61.5 & 51.5 & $70.56^{a}$ \\
\hline $\mathrm{pH} 4.5$ & 86.0 & 67.0 & 84.5 & 61.0 & 54.0 & 70.0 & 66.0 & 46.5 & 49.5 & $64.94^{\mathrm{b}}$ \\
\hline pH 3.5 & 89.0 & 73.5 & 86.5 & 55.0 & 68.5 & 57.5 & 70.5 & 58.0 & 42.0 & $66.72^{\mathrm{ab}}$ \\
\hline pH 2.5 & 0.0 & 9.5 & 1.0 & 5.0 & 0.0 & 24.0 & 20.0 & 2.5 & 0.0 & $6.89^{c}$ \\
\hline \multicolumn{11}{|c|}{ Abnormal seedling percentage (B) } \\
\hline pH 6.5 & 17.0 & 14.0 & 13.0 & 31.0 & 25.5 & 22.5 & 18.0 & 38.5 & 34.5 & $23.78^{c}$ \\
\hline pH 5.5 & 13.5 & 11.5 & 5.5 & 35.5 & 18.5 & 31.0 & 23.0 & 36.5 & 37.0 & $23.56^{\mathrm{c}}$ \\
\hline $\mathrm{pH} 4.5$ & 10.0 & 15.0 & 13.5 & 31.5 & 42.5 & 22.5 & 27.0 & 50.5 & 42.5 & $28.33^{\mathrm{b}}$ \\
\hline pH 3.5 & 10.5 & 17.0 & 12.5 & 35.5 & 27.5 & 38.5 & 29.0 & 40.5 & 52.5 & $29.28^{\mathrm{b}}$ \\
\hline pH 2.5 & 98.0 & 79.5 & 97.5 & 87.5 & 96.0 & 70.5 & 79.0 & 96.5 & 94.5 & $88.78^{a}$ \\
\hline Average (A) & $68.0^{\mathrm{A}}$ & $60.7^{\mathrm{B}}$ & $70.7^{\mathrm{A}}$ & $48.7^{\mathrm{C}}$ & $54.2^{\mathrm{BC}}$ & $55.9^{\mathrm{B}}$ & $60.6^{\mathrm{B}}$ & $45.8^{\mathrm{CD}}$ & $40.8^{\mathrm{D}}$ & \\
\hline Average (B) & $29.8^{C}$ & $27.4^{\mathrm{CD}}$ & $28.4^{\mathrm{CD}}$ & $44.2^{\mathrm{B}}$ & $42.0^{\mathrm{B}}$ & $37.0^{\mathrm{BC}}$ & $35.2^{\mathrm{C}}$ & $52.5^{\mathrm{A}}$ & $52.2^{\mathrm{A}}$ & \\
\hline \multicolumn{11}{|c|}{$5 \%$ DMRT of interaction $(\mathrm{A})=13.838 ; \mathrm{CV}(\mathrm{a}) *=15.0 ; \mathrm{CV}(\mathrm{b}) * *=24.2$} \\
\hline
\end{tabular}

length ratio showed that average values were reduced by simulated acid rain at $\mathrm{pH}$ 5.5-2.5. The highest root/shoot length ratios were recorded for TTCP, RD57, KTH17 and MLL cultivars at 1.27, 1.18, 1.15 and 1.02, respectively. The results indicated that root/shoot length ratio was significantly affected by simulated acid rain. Among the rice cultivars, root/shoot length ratio responded differently to simulated acid rain at different $\mathrm{pH}$ levels. Rice seedling root characteristics were inhibited by simulated acid rain; however, the inhibition effect was dependent on rice cultivars. Numerous adventitious roots (crown roots) arising from successive nodes of rice seedlings form the main components of the fibrous root system. This is important for crops to anchor and absorb water and nutrition [20]. Simulated acid rain at $\mathrm{pH} 2.5$ inhibited crown root formation of the rice seedlings. The number of crown roots per seedling of rice exposed to simulated acid rain was significant across all $\mathrm{pH}$ levels; although the number of crown roots per seedling exposed to simulated acid rain at $\mathrm{pH}$ 6.5-3.5 was not significant, the length of crown roots reduced. The results indicated that simulated acid rain inhibited cell differentiation of crown roots in rice seedlings. Among rice cultivars, the highest number of crown roots were found in landraces HPYTD, TTCP, KKN and MLL. Average number of crown roots per seedling for these four cultivars was 5.90, 5.65, 5.45 and 5.35, respectively.

Correlation analysis of germination percentage and four seedling characteristics of the nine Thai rice cultivars subjected to simulated acid rain was investigated (Table 3 ). The results showed that germination percentage significantly correlated with root length and root per shoot ratio (0.581 and 0.584 , respectively) and gave a highly significant negative correlation with abnormal seedling percentage $(-0.985)$. Root length was highly significantly correlated with root/shoot ratio (0.934) and significantly negatively correlated with abnormal seedling percentage $(-0.591)$. Root per shoot ratio had significant negative correlation with abnormal seedling percentage $(-0.593)$. These results indicated that tolerance ability and seed germination percentages of Thai rice cultivars impacted by simulated acid rain affected germination percentages and seedling root characteristics. These results were not completely conclusive but could be used for planning future research proposals.

\section{Promotional and inhibitory effects of simulated acid rain on Thai rice cultivars}

The promotional and inhibitory effects of simulated acid rain on nine Thai rice cultivars during seed germination were investigated (Table 4). Promo- 
Table 2 Mean values of seedling characteristics of nine Thai rice cultivars exposed to simulated acid rain during seed germination.

\begin{tabular}{|c|c|c|c|c|c|c|c|c|c|c|}
\hline \multirow{2}{*}{ pH level } & \multicolumn{9}{|c|}{ Cultivar } & \multirow{2}{*}{ Average } \\
\hline & $\mathrm{RD} 27$ & CMJ & KDML105 & KTH17 & RD57 & MLL & TTCP & $\mathrm{KKN}$ & HPYTD & \\
\hline \multicolumn{11}{|c|}{ Shoot height (A) } \\
\hline pH 6.5 & 5.85 & 6.64 & 6.25 & 6.52 & 6.59 & 7.50 & 6.48 & 5.98 & 5.96 & 6.42 \\
\hline pH 5.5 & 6.82 & 6.93 & 6.63 & 6.92 & 7.19 & 7.90 & 6.26 & 6.37 & 6.15 & 6.80 \\
\hline $\mathrm{pH} 4.5$ & 7.10 & 6.83 & 6.98 & 6.78 & 6.47 & 8.12 & 5.88 & 6.26 & 5.79 & 6.69 \\
\hline pH 3.5 & 7.83 & 6.81 & 6.66 & 6.89 & 7.03 & 8.55 & 5.90 & 6.37 & 6.28 & 6.92 \\
\hline pH 2.5 & 7.14 & 6.12 & 7.45 & 5.37 & 4.33 & 9.14 & 6.97 & 6.91 & 7.81 & 6.80 \\
\hline Average & $6.95^{\mathrm{B}}$ & $6.67^{\mathrm{B}}$ & $6.79^{\mathrm{B}}$ & $6.50^{\mathrm{B}}$ & $6.32^{\mathrm{BC}}$ & $8.24^{\mathrm{A}}$ & $6.30^{\mathrm{BC}}$ & $6.38^{\mathrm{BC}}$ & $6.39^{\mathrm{BC}}$ & \\
\hline \multicolumn{11}{|c|}{ Root length (B) } \\
\hline pH 6.5 & 6.37 & 6.11 & 6.84 & 9.78 & 10.47 & 8.62 & 8.75 & 6.12 & 5.87 & $7.66^{\mathrm{a}}$ \\
\hline pH 5.5 & 5.79 & 6.00 & 5.68 & 9.19 & 10.47 & 8.80 & 8.61 & 5.19 & 5.75 & $7.27^{\mathrm{a}}$ \\
\hline $\mathrm{pH} 4.5$ & 5.32 & 4.99 & 4.90 & 8.24 & 8.36 & 8.81 & 8.48 & 5.70 & 5.36 & $6.68^{\mathrm{b}}$ \\
\hline pH 3.5 & 4.86 & 4.79 & 4.57 & 8.10 & 9.18 & 9.22 & 8.38 & 5.62 & 4.99 & $6.63^{\mathrm{b}}$ \\
\hline pH 2.5 & 1.57 & 2.25 & 1.67 & 2.42 & 1.08 & 5.73 & 4.60 & 3.15 & 2.10 & $2.73^{c}$ \\
\hline Average & $4.78^{\mathrm{C}}$ & $4.83^{\mathrm{C}}$ & $4.73^{\mathrm{C}}$ & $7.54^{\mathrm{AB}}$ & $7.91^{\mathrm{A}}$ & $8.23^{\mathrm{A}}$ & $7.76^{\mathrm{A}}$ & $5.15^{\mathrm{C}}$ & $4.81^{\mathrm{C}}$ & \\
\hline \multicolumn{11}{|c|}{ Root/shoot length ratio (C) } \\
\hline $\mathrm{pH} 6.5$ & 1.11 & 0.94 & 1.11 & 1.52 & 1.59 & 1.13 & 1.42 & 1.03 & 0.99 & $1.20^{\mathrm{a}}$ \\
\hline pH 5.5 & 0.86 & 0.88 & 0.88 & 1.35 & 1.46 & 1.13 & 1.38 & 0.82 & 0.94 & $1.08^{\mathrm{b}}$ \\
\hline $\mathrm{pH} 4.5$ & 0.76 & 0.74 & 0.70 & 1.24 & 1.28 & 1.11 & 1.46 & 0.92 & 0.93 & $1.01^{\mathrm{c}}$ \\
\hline pH 3.5 & 0.63 & 0.74 & 0.70 & 1.20 & 1.31 & 1.09 & 1.43 & 0.90 & 0.81 & $0.98^{\mathrm{c}}$ \\
\hline pH 2.5 & 0.22 & 0.38 & 0.22 & 0.43 & 0.25 & 0.63 & 0.66 & 0.46 & 0.27 & $0.39^{\mathrm{e}}$ \\
\hline Average & $0.72^{\mathrm{DE}}$ & $0.73^{\mathrm{DE}}$ & $0.72^{\mathrm{DE}}$ & $1.15^{\mathrm{B}}$ & $1.18^{\mathrm{B}}$ & $1.02^{\mathrm{C}}$ & $1.27^{\mathrm{A}}$ & $0.83^{\mathrm{D}}$ & $0.79^{\mathrm{D}}$ & \\
\hline \multicolumn{11}{|c|}{ Number of crown roots per seedling (D) } \\
\hline $\mathrm{pH} 6.5$ & 3.75 & 5.50 & 4.75 & 4.50 & 4.75 & 5.00 & 6.25 & 6.75 & 5.50 & $5.19^{\mathrm{a}}$ \\
\hline pH 5.5 & 4.25 & 5.00 & 4.50 & 4.00 & 4.00 & 6.00 & 6.00 & 4.50 & 5.00 & $4.81^{\mathrm{a}}$ \\
\hline $\mathrm{pH} 4.5$ & 4.00 & 4.25 & 3.75 & 3.75 & 4.00 & 5.75 & 6.25 & 5.75 & 6.00 & $4.83^{\mathrm{a}}$ \\
\hline pH 3.5 & 4.50 & 3.75 & 5.25 & 4.25 & 5.25 & 5.00 & 5.75 & 5.25 & 6.50 & $5.06^{\mathrm{a}}$ \\
\hline pH 2.5 & 1.50 & 3.25 & 1.00 & 3.75 & 2.25 & 5.00 & 4.00 & 5.00 & 6.50 & $3.58^{\mathrm{b}}$ \\
\hline Average & $3.60^{\mathrm{BC}}$ & $4.35^{\mathrm{B}}$ & $3.85^{\mathrm{B}}$ & $4.05^{\mathrm{B}}$ & $4.05^{\mathrm{B}}$ & $5.35^{\mathrm{A}}$ & $5.65^{\mathrm{A}}$ & $5.45^{\mathrm{A}}$ & $5.90^{\mathrm{A}}$ & \\
\hline
\end{tabular}

$5 \%$ DMRT of Interaction $(\mathrm{A})=1.070 ; \mathrm{CV}(\mathrm{a}) *=9.8 ; \mathrm{CV}(\mathrm{b}) * *=11.4$

$5 \%$ DMRT of Interaction $(B)=1.211 ; \mathrm{CV}(\mathrm{a}) *=14.2 ; \mathrm{CV}(\mathrm{b}) * *=14.0$

$5 \%$ DMRT of Interaction $(C)=0.324$; CV (a)* $=12.1 ; \mathrm{CV}(\mathrm{b}) * *=12.4$

$5 \%$ DMRT of Interaction (D) $=1.620 ; \mathrm{CV}(\mathrm{a}) *=24.6 ; \mathrm{CV}(\mathrm{b}) * *=24.7$

* CV (a) indicates the degree of precision attached to the main plot factor.

${ }^{* *} \mathrm{CV}$ (b) indicates the precision of the subplot factor and its interaction with the main plot factor.

Table 3 Correlation analysis of germination percentages and seedling characteristics of nine Thai rice cultivars subjected to different $\mathrm{pH}$ levels during seed germination $\left(R^{2}=90.5 \%\right)$.

\begin{tabular}{|c|c|c|c|c|c|c|}
\hline Traits & SH & RL & $\mathrm{R} / \mathrm{S}$ & $\mathrm{CR}$ & $\mathrm{AB}$ & GR \\
\hline SH & 1 & & & & & \\
\hline $\mathrm{RL}$ & 0.243 & 1 & & & & \\
\hline $\mathrm{R} / \mathrm{S}$ & -0.074 & $0.934 * *$ & 1 & & & \\
\hline CR & 0.047 & 0.307 & 0.329 & 1 & & \\
\hline$A B$ & -0.063 & $-0.591^{*}$ & $-0.593^{*}$ & -0.255 & 1 & \\
\hline GR & 0.069 & $0.581^{*}$ & $0.584^{*}$ & 0.245 & $-0.985^{* *}$ & 1 \\
\hline
\end{tabular}


Table 4 Promotional and inhibitory percentages of seed germination and seedling characteristics of nine Thai rice cultivars affected by simulated acid rain at different pH levels compared with $\mathrm{pH} 6.5$ as the control.

\begin{tabular}{|c|c|c|c|c|c|}
\hline Trait & Shoot height & Root length & $\begin{array}{l}\text { Root/shoot } \\
\text { length ratio }\end{array}$ & $\begin{array}{l}\text { Crown roots } \\
\text { per seedling }\end{array}$ & $\begin{array}{l}\text { Germination } \\
\text { percentage }\end{array}$ \\
\hline pH 5.5 & 6.40 & $-4.98^{c}$ & $-10.28^{b c}$ & $-0.61^{b c}$ & $-1.02^{\mathrm{b}}$ \\
\hline pH 4.5 & 4.54 & $-12.23^{\mathrm{b}}$ & $-15.61^{b}$ & $-9.11^{\mathrm{b}}$ & $-1.93^{\mathrm{b}}$ \\
\hline pH 3.5 & 8.13 & $-13.38^{\mathrm{b}}$ & $-18.56^{\mathrm{b}}$ & $-6.72^{\mathrm{b}}$ & $5.41^{\mathrm{b}}$ \\
\hline pH 2.5 & 6.51 & $-63.57^{\mathrm{a}}$ & $-66.63^{a}$ & $-90.09^{a}$ & $-32.77^{a}$ \\
\hline Grand mean & 6.40 & -23.54 & -27.77 & -26.63 & -7.58 \\
\hline RD27 & $23.93^{c}$ & $-30.02^{\mathrm{a}}$ & $-44.42^{\mathrm{a}}$ & $-19.25^{\mathrm{b}}$ & $-4.17^{\mathrm{a}}$ \\
\hline CMJ & $0.96^{\mathrm{a}}$ & $-25.99^{\mathrm{ab}}$ & $-26.07^{b}$ & $-27.00^{\mathrm{ab}}$ & $-25.21^{\mathrm{a}}$ \\
\hline KDML105 & $10.82^{\mathrm{ab}}$ & $-36.91^{\mathrm{a}}$ & $-42.27^{\mathrm{a}}$ & $-23.35^{\mathrm{ab}}$ & $-20.31^{\mathrm{a}}$ \\
\hline KTH17 & $-0.34^{\mathrm{a}}$ & $-28.51^{\mathrm{a}}$ & $-30.09^{b}$ & $-31.80^{\mathrm{a}}$ & $-10.63^{a}$ \\
\hline RD57 & $-5.04^{\mathrm{a}}$ & $-30.09^{\mathrm{a}}$ & $-32.47^{b}$ & $-28.26^{\mathrm{ab}}$ & $3.57^{\mathrm{ab}}$ \\
\hline MLL & $6.35^{\mathrm{ab}}$ & $-7.53^{\mathrm{bc}}$ & $-12.33^{c}$ & $-16.41^{\mathrm{bc}}$ & $2.60^{\mathrm{ab}}$ \\
\hline ТТСР & $3.02^{\mathrm{a}}$ & $-12.26^{\mathrm{b}}$ & $-12.88^{c}$ & $-22.48^{\mathrm{ab}}$ & $0.16^{\mathrm{ab}}$ \\
\hline KKN & $8.47^{\mathrm{ab}}$ & $-18.33^{\mathrm{b}}$ & $-24.16^{b}$ & $-29.53^{\mathrm{ab}}$ & $-23.81^{\mathrm{a}}$ \\
\hline HPYTD & $9.40^{\mathrm{ab}}$ & $-22.24^{\mathrm{ab}}$ & $-25.25^{\mathrm{b}}$ & $-41.60^{a}$ & $9.58^{\mathrm{ab}}$ \\
\hline Grand mean & 6.40 & -23.54 & -27.77 & -26.63 & -7.58 \\
\hline
\end{tabular}

Mean values followed by the same letter in the same column are not significantly different at the $5 \%$ level by DMRT.

tional and inhibitory percentages of seed germination, shoot length, root length, root/shoot length ratio and number of crown roots per seedling were calculated following the equation developed by Nawanopparatsakul et al [21]. The results revealed that shoot height of seedlings was not significantly different; however, the acidity of simulated acid rain affected seedling shoot height. Promotional and inhibitory percentages of seedling root length were highly significantly inhibited by the acidity of simulated acid rain with the highest inhibitory percentages at pH $2.5(-63.57 \%)$. Root/shoot length ratio was highly significantly inhibited by the acidity of simulated acid rain with the highest inhibitory percentage value at $\mathrm{pH} 2.5(-66.63 \%)$. The number of crown roots per seedling was inhibited by the acidity of simulated acid rain at $\mathrm{pH} 2.5$ showing the highest inhibitory percentage $(-90.09 \%)$. Germination percentage was highly significantly reduced by the acidity of simulated acid rain, with $\mathrm{pH} 2.5$ giving the highest inhibitory percentage $(-32.77 \%)$. However, acidity of simulated acid rain at $\mathrm{pH} 3.5$ stimulated germination percentage of rice by $5.41 \%$.

The results suggested that simulated acid rain inhibited root length, root/shoot length ratio and number of crown roots per seedling in all rice cultivars while seedling shoot height and germination percentages were either promoted or inhibited by simulated acid rain, depending on $\mathrm{pH}$ levels. Seedling shoot height was stimulated in RD27, CMJ,
KDML105, MLL, KKN, TTCP and HPYTD cultivars with promotional percentages of 23.93, 0.96, 10.82, $6.35,8.47,3.02$ and $9.40 \%$, respectively. Seedling shoot height was inhibited in KTH17 and RD57 cultivars at $-0.34 \%$ and $-5.04 \%$, respectively. Inhibitory percentage of root length was high in RD27, CMJ, KDML105, KTH17, RD57 and HPYTD cultivars at $-30.02,-25.99,-36.91,-28.51,-30.09$ and $-22.24 \%$, respectively. The results indicated that simulated acid rain highly inhibited root characteristics of these rice cultivars. Root per shoot length ratio was highly significantly inhibited in RD27 $(-44.42 \%)$ and KDML105 $(-42.27 \%)$ cultivars; however, inhibitory percentages were high in CMJ $(-26.07 \%)$, KTH17 (-30.09\%), RD57 (-32.47\%), KKN $(-24.16 \%)$ and HPYTD $(-25.25 \%)$ cultivars. The number of crown roots per seedling was highly inhibited in CMJ (-27\%), KDML105 $(-23.35 \%)$, KTH17 (-31.8\%), RD57 (-28.26\%), TTCP $(-22.48 \%)$, KKN $(-29.53 \%)$ and HPYTD $(-49.6 \%)$ cultivars. Germination percentages were either stimulated or inhibited in rice cultivars. The results showed a stimulation effect in RD57 (3.57\%), MLL (2.6\%), TTCP $(0.16 \%)$ and HPYTD (9.58\%) cultivars but inhibition in RD27 $(-4.17 \%)$, CMJ (-25.21\%), KDML105 (-20.31\%), KTH17 $(-10.63 \%)$ and KKN $(-23.81 \%)$ cultivars. The results indicated that rice cultivars had different tolerances to simulated acid rain during the seed germination stage. 


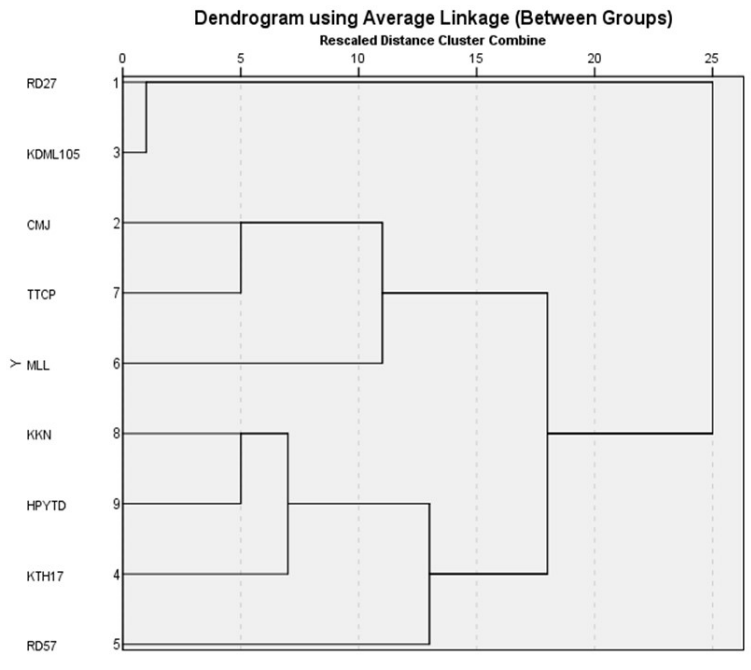

Fig. 2 Cluster analysis of nine Thai rice cultivars based on germination percentages and seedling characteristics affected by simulated acid rain at different $\mathrm{pH}$ levels.

\section{Cluster analysis of nine Thai rice cultivars based on germination percentages and seedling characteristics}

Cluster analysis of nine Thai rice cultivars was performed based on the Euclidean distance coefficient using germination percentages and seedling characteristics affected by simulated acid rain at different $\mathrm{pH}$ levels as shown in Fig. 2. Results showed wide ranges of germination percentages and seedling characteristics. Rice cultivars in the dendrogram were classified into two clusters with distance coefficients ranging from 1.00 to 25.00 . The first cluster consisted of two cultivars (RD27 and KDML105) with seven cultivars in the second cluster. The second cluster was classified into two sub-clusters including sub-cluster 2.1 (CMJ, TTCP and MLL) and sub-cluster 2.2 (KKN, HPYTD, KTH17 and RD57). Germination percentage mean values of the first cluster were high while average values of the second cluster were high on seedling characteristics. The results indicated that the second cluster had more tolerance to simulated acid rain than the first cluster. Therefore, the second cluster could be used as tolerant germplasm for rice breeding programs in the future.

\section{DISCUSSION}

Environmental factors including acid rain, drought, cold, salinity, ozone levels and heat stress impact plant distribution, growth, development and productivity. Results of this study showed that ger- mination of rice exposed to simulated acid rain at $\mathrm{pH}$ 2.5-4.5 decreased compared to the control. Zabawi et al [17] reported that germination of rice MR84 cultivar reduced on exposure to simulated acid rain at $\mathrm{pH}$ 3.5. Simulated acid rain also reduced tiller number and leaf number, leading to reduced seed yield. In other plant species, seed germination was remarkably inhibited by $\mathrm{pH} 2.0$ water [14, 15]. Tong and Zhang [22] suggested that simulated acid rain had a promotional or inhibitory effect on growth of different tree species, indicating that the response of plants to simulated acid rain depended on species. Cluster analysis revealed that rice cultivars responded differently to simulated acid rain. Satoh et al [23] suggested that simulated acid fog treatments induced the expression of genes involved in the defense and stress responses in rice plants.

The effect of simulated acid rain on seedling characteristics of rice showed significantly decreased seedling root length, root per shoot ratio and number of crown roots per seedling while irregular differentiation of roots was also found. However, root cell differentiation was not investigated. Root length was reduced by simulated acid rain at $\mathrm{pH} 4.5$, concurring with the report from Shaukat and Shafiq [24]. Fan and Li [15] observed that seedling growth of five broad-leaved species exposed to simulated acid rain at $\mathrm{pH} 2.0$ was inhibited while seedling growth was stimulated by acid rain at pH 3.5-5.0. Gabara et al [25] reported that simulated acid rain caused the alteration of chloroplasts and mitochondria in Lycopersicon esculentum Mill. leaves while Zabawi et al [17] reported that plant height was not reduced by simulated acid rain and that the promotional and inhibitory effects of simulated acid rain depended on rain sulfate content. The effect of simulated acid rain has been investigated in different plant species for severity effects and different levels of plant physiology and biochemistry.

Biochemical effects on antioxidative enzymes during rice seed germination exposed to simulated acid rain at $\mathrm{pH}<3.5$ caused reduction in peroxidase and catalase activity [18]. Simulated acid rain at $\mathrm{pH}<1.5$ caused changes in the metabolism of the antioxidative system of Georgia wheat species [26]. Satoh et al [23] revealed that simulated acid fog caused similar responses to biotic stresses and ozone stress. The apoplast genes encoding $N A D P H$ oxidase and germin were also induced by simulated acid fog and biotic stresses. Velikova et al [27] reported that simulated acid rain significantly increased per- 
oxidase activity and decreased catalase activities during the first hours after treatment in bean. This result indicated that morphological and physiological characteristics of plants were affected by acid rain in different ways depending on plant species, varieties, growth stages and growing conditions. Future research should investigate the effects of simulated acid rain on rice growth development and yield potential and also identify the genes related to acid tolerance ability to enhance breeding program yields.

\section{CONCLUSION}

The effect of simulated acid rain was investigated during rice seed germination. The impact of simulated acid rain on growth and yield of rice has been studied in several countries; however, the preliminary response of selected Thai rice cultivars exposed to simulated acid rain during seed germination has never been investigated. The results revealed that simulated acid rain at $\mathrm{pH} 2.5$ inhibited rice seedling growth and seed germination. This level of acidity does not occur consistently in the environment in Thailand; however, simulated acid rain at $\mathrm{pH}<4.5$ also impacted seed germination and seedling growth of rice and might cause rice yield reduction.

Acknowledgements: This research was partially supported by the Center for Advanced Studies for Agriculture and Food, Institute for Advanced Studies, Kasetsart University under the Higher Education Research Promotion and National Research University Project of Thailand. The authors would like to thank the Center for Advanced Studies for Agriculture and Food (CASAF), Kasetsart University, Bangkok, Thailand for financially supporting this Post Master Research Project and the Central Laboratory and Greenhouse Complex of the Faculty of Agriculture, Kasetsart University, Bangkok, Thailand for laboratory instrument support.

\section{REFERENCES}

1. Ouyang ZJ, Zhou GY, Huang ZL, Liu JX, Zhang DQ, Li J (2008) Effect of simulated acid rain on potential carbon and nitrogen mineralization in forest soils. Pedosphere 18, 503-514.

2. Nagase Y, Silva ECD (2007) Acid rain in China and Japan: A game-theoretic analysis. Reg Sci Urban Econ 37, 100-120.

3. Shvetsova T, Mwesigwa J, Labady A, Kelly S, Thomas D, Lewis K, Volkov AG (2002) Soybean electrophysiology: effects of acid rain. Plant Sci 162, 723-731.

4. Acid Deposition Monitoring Network in East Asia (EANET) (2011) Second Periodic Report on the State of Acid Deposition in East Asia (Part III), EANET, Bangkok, Thailand.

5. Acid Deposition Monitoring Network in East Asia (EANET) (2010) Countries Effort and Achievements in Combating Acid Deposition, EANET, Bangkok, Thailand.

6. Mallika P, Rattapon O (2008) A four-year investigation on wet deposition in western Thailand. J Environ Sci 20, 441-448.

7. Thepanondh S, Ayers GP, Hooper MA (2005) Analysis of precipitation chemistry in Northern Thailand. Clean Air Environ Qual 39, 43-49.

8. Chaichana N (2019) Analysis of nutritional composition, antioxidant activity and callus induction of Oryza sativa cultivars Khumthan and Norprae. ScienceAsia 45, 509-514.

9. Chaipanich VV, Roberts DL, Yenchon S, Te-chato S, Divakaran M (2020) In vitro seed germination and plantlet regeneration of Vanilla siamensis: An endemic species in Thailand. ScienceAsia 46, 315-322.

10. Shaukat SS, Khan MA (2008) Growth and physiological responses of tomato (Lycopersicon esculentum Mill.) to simulated acid rain. Pak $J$ Bot 40, 2427-2435.

11. Ruuhola T, Rantala LM, Neuvonen S, Yang S, Rantala MJ (2009) Effects of long-term simulated acid rain on plant-herbivore interaction. Basic Appl Ecol 10, 589-596.

12. Ramlall M, Varghese B, Ramdhani S, Pammenter NW, Bhatt A, Berjak P, Sershen (2015) Effect of simulated acid rain on germination, seedling growth and oxidative metabolism of recalcitrant-seeded Trichilia dregeana grown in its natural seed bank. Physiol Plantarum 153, 149-160.

13. Wang X, Liu Z, Niu L, Fu B (2013) Long-term effect of simulated acid rain stress on a stable forest plant, Pinus massoniana Lamb: a proteomic analysis. Trees 27, 297-302.

14. Fan HB, Wang YH (2000) Effects of simulated acid rain on germination, foliar damage, chlorophyll contents and seedling growth of five hardwood species growing in China. For Ecol Manage 126, 321-329.

15. Fan H, Li C (1999) Effects of simulated acid rain on seedling emergence and growth of five broad-leaved species. J For Res 10, 83-86.

16. Feng ZW, Cao HF, Zhou XP (1999) The effect of acid deposition on ecosystem and restoration techniques. China Environ Sci Press, 2-3.

17. Zabawi AG, Esa SM, Leong CP (2008) Effects of simulated acid rain on germination and growth of rice plant. J Trop Agric Food Sci 36, 281-286.

18. Wang L, Haung X, Zhou Q (2008) Response of peroxidase and catalase to acid rain stress during seed germination of rice, wheat and rape. Front Environ Sci Engin China 2, 364-369.

19. Don R (2009) ISTA Handbook on Seedling Evaluation, International Seed Testing Association, Bassersdorf, 
Switzerland.

20. Wang XF, Hea FF, Maa XX, Maoa CZ, Hodgmanb C, Lub CG, Wua P (2011) OsCAND1 is required for crown root emergence in rice. Mol Plant 4, 289-299.

21. Nawanopparatsakul S, Phuagphong P, Kitcharoen N (2012) Effect of citrus extractions on plant growth inhibition by Lettuce (Lactuca sativa $\mathrm{L}$ ) seed germination and seedling length bioassay. $J$ Pharm Biomed Sci 22, 1-4.

22. Tong S, Zhang L (2014) Differential sensitivity of growth and net photosynthetic rates in five tree species seedlings under simulated acid rain stress. Pol J Environ Stud 23, 2259-2264.

23. Satoh K, Saji S, Ito S, Shimizu H, Saji H, Kikuchi S (2014) Gene response in rice plants treated with continuous fog influenced by $\mathrm{pH}$, was similar to that treated with biotic stress. Rice 7, ID 10.
24. Shaukat SS, Shafiq N (1998) Effects of simulated acid rain on germination and seedling growth of some wild and cultivated species. Pak J Bot 1, 219-222.

25. Gabara B, Sklodowska M, Wyrwicka A, Glinska S, Gapinska M (2003) Changes in the ultrastructure of chloroplasts and mitochondria and antioxidant enzyme activity in Lycopersicon esculentum Mill. leaves sprayed with acid rain. Plant Sci 164, 507-516.

26. Kacharava N, Chkhubianishvili E, Badridze G, Chanishvili S, Mazanishvili L (2013) Antioxidant response of some Georgian wheat species to simulated acid rain. Aust J Crop Sci 7, 770-776.

27. Velikova V, Yordanov I, Edreva A (2000) Oxidative stress and some antioxidant systems in acid raintreated bean plants Protective role of exogenous polyamines. Plant Sci 151, 59-66. 